\title{
A GESTÃO DA INFORMAÇÃO NAS ORGANIZAÇÕES
}

É evidente, na atualidade, que nada poderia funcionar sem uma quantidade significativa de informação como elemento que impulsiona os fenômenos sociais e que é por eles impulsionada. Pessoas e organizações - públicas ou privadas - dependem da informação em seus processos decisórios. Entretanto, para ser utilizada estrategicamente, é fundamental que a informação seja gerida em favor da sobrevivência e competitividade organizacional. Este processo, a gestão da informação (GI), é responsável por gerir tanto os recursos internos quanto os externos à organização.

A partir da década de 1980 a GI inicia uma trajetória de crescente importância na vida das organizações; importância que a coloca no mesmo patamar dos demais trabalhos e processos, como a gestão de $\mathrm{RH}$, gestão de processos, gestão de negócios. Assim, a GI passou a ser considerada mais uma atividade essencial, como qualquer outro tipo de trabalho desenvolvido nas organizações.

Cada organização tem um fluxo de informação que lhe é peculiar e este fluxo é objeto importante da GI que deve mapeálo, identificando pessoas, fontes de infor- mação, tecnologia utilizada, produtos e serviços, compondo esse conjunto estruturado de atividades relativas à forma como informação e conhecimento são obtidos, distribuídos e utilizados. Todas as etapas e atores do fluxo de informação precisam ser identificados e nomeados a fim de detectar as influências que exercem sobre o processo e antever problemas que possam surgir.

Para que isto se realize, a Gl deve se apoiar em políticas organizacionais que propiciem a sintonia e o inter-relacionamento entre as unidades ou setores da instituição. Esta é uma condição imprescindível para que os procedimentos direcionem os fluxos de informação para a gestão.

Mas, além desses, quais seriam os outros elementos fundamentais para a GI? Estamos falando de um processo que é social, portanto, as pessoas e suas relações, mais que qualquer outro elemento, são preponderantes para a efetivação da GI. Não há dúvida de que a credibilidade e o sucesso de qualquer projeto de GI será imputado às pessoas que o direcionam e o condicionam de acordo com os objetivos pretendidos. 
Além das pessoas, diferentes recursos de informação são mobilizados para que a gestão cumpra sua função. Esses recursos compreendem: tecnologia da informação, fontes, serviços e sistemas de informação. Portanto, a GI adere-se não apenas aos processos de organização da informação, mas também às necessidades de informação; centra-se nos fluxos e ações referentes à informação, e não somente nos sistemas de informação.

A GI refere-se ao conhecimento que pode ser coletado, processado e administrado, por isso foi incorporada às amplas questões que a gestão do conhecimento compreende. Nesta perspectiva a informação é um importante ativo para o compartiIhamento do conhecimento nas organizações.

Infelizmente a organização da informação ainda é um recurso inacessível para muitas instituições que não desenvolveram habilidades para capitalizar as informações que detêm ou têm acesso. Por essa razão a GI pode ser uma estratégia que maximiza recursos, em que as pessoas, por meio de suas atividades e produção, possam melhor compartilhar a informação. Em conseqüência serão criados ativos de conhe- cimento e informação que produzirão ambientes de aprendizagem que tragam maiores vantagens às organizações.

Ciente da importância da GI para a área de Ciência da Informação e para os profissionais que nela atuam, o Departamento de Ciência da Informação da Universidade Estadual de Londrina, propôs o Curso de Mestrado Profissional em Gestão da Informação. O Curso, cuja primeira oferta inicia-se no segundo semestre de 2008, pretende capacitar profissionais para o exercício das atividades de gestor da informação, expandir competências dos profissionais, aprofundar conhecimentos, ampliar cenários e espaços dedicados à informação, estimular a reflexão desses profissionais enriquecendo suas práticas, agregando novos conhecimentos e habilidades a seus espaços profissionais.

Com essas ações, o Departamento de Ciência da Informação da UEL contribui para a área de Ciência da Informação no Brasil, oferecendo aos profissionais - que por vários motivos não se enquadram no perfil do Mestrado Acadêmico - a possibilidade de formação especializada e qualificada em Pós-Graduação Stricto Sensu na modalidade Mestrado Profissional.

Terezinha Elisabeth da Silva

Editora

Maria Inês Tomaél

Membro do Comitê Editorial 